\title{
Det pedagogisk kritiske - et mangslungent landskap
}

\author{
Tone Kvernbekk \\ Universitetet $i$ Oslo, Norge
}

Universitetet er ofte ansett som et arnested for kritisk tenkning. Men det var en periode i universitetets tusenårige historie at kritisk tenkning ikke var noe framtredende trekk. Holbergs velkjente figur Erasmus Montanus (1731) studerer ved et universitet som er rigid i form og akterutseilt $\mathrm{i}$ innhold, som driver med unyttig terping av klassiske fag, holder seg med et avleggs lærdomsideal og dessuten lærer folk å bli akademisk tilgjorte og språklig jålete. Holberg bedrev satire, men deler av den var nok ganske treffende. For øvrig testamenterte Holberg hele formuen sin til Sorø Akademi, som på hans tid var et sentralt sted for samfunns- og systemkritisk tenkning i Danmark-Norge og en sterk konkurrent til universitetet (Collett, 1998). Men universitetet er en institusjon som er i stand til å fornye seg. I våre dager er det knapt et universitet i hele verden som ikke har «kritisk tenkning» som overordnet mål for sine studenter og som modus operandi for sine ansatte.

Det er ikke dermed sagt at alle er enige om hva det betyr å være en kritisk tenker, og slett ikke om hvordan man blir det. Det er mange måter å tenke om pedagogikk og kritikk på, og jeg skal i det følgende streife innom noen av dem. Dette er på ingen måte tenkt å være noen uttømmende diskusjon, men mer en vandring i et komplekst, mangfoldig og til dels uoversiktlig begrepsmessig landskap. Som en innledning kan vi

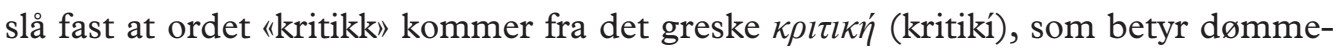
kraft, vurderingsevne, det å kunne skjelne og/eller identifisere personers eller tings verdi. Det er verdt å merke seg at selv om «kritikk» ofte assosieres med påpekning av feil, mangler eller negative trekk, innebar det opprinnelig en anerkjennelse også av sterke og gode kvaliteter, og en balansert «alt tatt i betraktning»-vurdering til slutt. Kritikk beveger seg innenfor et normativt område og hviler på eksplisitte og implisitte verdier, kriterier og normer. Dette åpner for interessante og vanskelige problemstillinger om f.eks. hvilke kriterier, verdier og normer som bør ligge til grunn for kritikken. Disse må argumenteres for, av to grunner. Den ene er at samfunn og kulturer kan holde seg med flere ulike verdisett samtidig, og disse kan stå i motstrid

\footnotetext{
^Korrespondanse: Tone Kvernbekk, e-post: tone.kvernbekk@iped.uio.no

(C) 2021 Tone Kvernbekk. This is an Open Access article distributed under the terms of the Creative Commons Attribution 4.0 International License (https://creativecommons.org/licenses/by-nc/4.0/), allowing third parties to copy and redistribute the material in any medium or format and to remix, transform, and build upon the material for any purpose, even commercially, provided the original work is properly cited and states its license. 


\section{T. Kvernbekk}

til hverandre. Mål, som hver for seg er aktverdige, kan kollidere med hverandre og til og med utelukke hverandre. Den andre grunnen er at kriterier, verdier og normer endres over tid. De skal ikke tas for gitt.

Med dette som bakgrunn skal jeg foreta noen streiftog i det mangslungne landskapet som omfatter pedagogikk og kritikk og antyde noen snublesteiner. Vi begynner midt i den pedagogiske praksisen.

\section{Det pedagogisk uferdige}

Pedagogisk praksis omfatter en rekke ulike endringsprosesser. Alle pedagogiske prosesser, enten vi kaller dem oppdragelse, læring, utvikling, sosialisering, utdanning eller danning, inneholder tid. De handler om å være underveis mot mer eller mindre klart definerte mål, som man når eller ikke når. Prosesser avsluttes på noe tidspunkt kort eller langt fram i tid, som en utdanning, eller de avsluttes ikke i det hele tatt, som danningsprosesser. Pedagogiske prosesser karakteriseres i det hele tatt av å være uferdige, uavsluttete og prinsipielt uforutsigbare; de kan i prinsippet ta mange forskjellige retninger og bli til noe helt annet enn det vi planla. Hvor rimelig er det å kritisere (i betydningen vurdere negativt) prosesser som ikke når fram til sine planlagte mål i løpet av den tilmålte tida, som ikke kommer seg fra uferdig til en tilstand vi definerer som ferdig? Det er i denne sammenhengen verdt å minne om følgende visdomsord, tillagt den tyske (og senere amerikanske) teologen og filosofen Paul Tillich (1886-1965): "The fatal pedagogical error is to throw answers like stones at the heads of those who have not yet asked the questions.» En tanke som har bestemt seg i utgangspunktet, er ikke en kritisk tanke, den er snarere motsatsen. Og hvis noen andre har bestemt for deg hva slags tanker du skal tenke, tanker som er ferdige, begynner det å ligne på indoktrinering. En mistanke, derimot, sier Asbjørn Aarnes og Helge Salemonsen (1987, s. 7), er en tanke som nettopp ikke har bestemt seg ennå. Mistanken reserverer seg, stiller seg prøvende og tvilende, og antar at ting ikke nødvendigvis er det de utgir seg for å være. Dette innebærer ikke at vi skal gå rundt og tro at folk forstiller seg eller konspirerer, eller at ingenting er som det ser ut. Mistanken må holde et strengt blikk på seg selv, så den ikke glir over til å bli en uhemmet og lammende skeptisisme. Men det betyr at tenkningen må kunne ta omveier fram mot målet (som i deres sammenheng er innsikt). Den må studere tegn, informasjon, paradokser og motsigelser, veie fram og tilbake og etter hvert danne seg en oppfatning. Den må få lov til å være uferdig og bruke den tida den trenger. Denne formen for omveis-tenkning blir naturligvis vanskelig hvis noen allerede har kastet svarene i hodet på deg - og særlig hvis de ikke har fortalt deg hva spørsmålene er, eller gitt deg tid og plass til å formulere dine egne spørsmål. Så kan vi jo legge inn her en fundering over det menneskelige mangfold: Noen liker å få svarene uten å måtte bekymre seg om spørsmålene, og uten å måtte ta tankemessige omveier. Noen er i problematiseringsbransjen. Noen tar tankemessige omveier hele tida, og lander kanskje aldri på synspunkter de vil forsvare. 


\section{Motsatser og omliggende landskap}

Det ligger i kortene at det pedagogisk kritiske har mye til felles med mistanken slik Aarnes og Salemonsen utlegger den. Det må få lov til å være underveis, til å være uferdig i alle fall en stund. Men dette i seg selv bringer oss ikke nærmere et innhold i begrepet. Vi søker råd hos den danske pedagogiske filosofen Knud Grue-Sørensen: «Og lad mig her benytte et kunstgreb, som jeg ofte benytter og anbefaler de studerende å benytte, når de vil skaffe sig klarhed over et begreb, nemlig at se på, hvad der er det motsatte", sier han (1974, s. 37). Dette er et utmerket råd, og jeg skal benytte meg av samme kunstgrep. Som motsats til en kritisk innstilling setter Grue-Sørensen (1904-1992) godtroenhet og en blindt aksepterende holdning. Han skiller mellom kritisk tenkning og kritisk holdning, og hevder at holdning er mer fundamentalt enn tenkning:

[En alternativ forklaring] ville i sig selv være et stykke opfindsom eller produktiv tænkning, der kunne være, men ikke behøvede at være forbundet med en kritisk indstilling alt eftersom man holdt sig åben for andre mulige forklaringer eller mente at have fundet den eneste mulige (s. 37).

Tenkning, sier Grue-Sørensen, er en oppfinnsom operasjon med begreper. Mens en kritisk holdning har sin motsats i en ukritisk holdning, har vi ikke noen klar motsats til kritisk tenkning, mener han. Hva skulle ukritisk tenkning være? Treg eller uoppfinnsom tenkning? Ulogisk? Men vi sier ikke om folk som ikke klarer å løse en komplisert oppgave at de tenker ukritisk; vi sier at de mangler kunnskap eller ferdigheter. Heller ikke er det noen automatikk i at folk som tenker logisk derved tenker kritisk. Det kritiske ligger i en annen dimensjon, sier Grue-Sørensen, mye mer i holdningen og viljen enn $i$ tenkningen.

Spranget til anglo-amerikansk litteratur er stort. Der er tendensen heller at man snur forholdet på hodet og setter kritisk tenkning som det fundamentale, slik at holdninger, vilje og karaktertrekk er omfattet av dette. Det kan naturligvis være flere motsatser til kritisk tenkning, men særlig to er mye diskutert: "closed-mindedness» (f.eks. Callan \& Arena, 2009) og «non-evidential styles of belief» (f.eks. Siegel, 1988). Begge disse er ansett for å være resultater av indoktrinering, som dermed blir den kritiske tenkningens fremste fiende. Indoktrinering er nært beslektet med Tillichs fatale pedagogiske mistak, med å kaste ferdige svar i hodet på elever og studenter. Mens Callan og Arena og Siegel har ulike oppfatninger av hva indoktrineringens resultat består i, har de samme tilnærmingen: de ser på det hovedsakelig ut fra resultatet, på virkningen det har på elevers og studenters læring og oppfatninger. Andre tilnærminger er også mulige. Det går an å definere indoktrinering ut fra lærerens hensikt (vi ønsker at studentene skal tilegne seg bestemte oppfatninger og holde dem for sanne), undervisningsmetodene som brukes (ingen kritiske eller undrende spørsmål tillates, bare ett riktig svar, ingen anledning til refleksjon over gitte forutsetninger eller egne løsningsforslag), eller innholdets doktrinære vesen (det insisterer på sin 


\section{T. Kvernbekk}

egen sannhet). Men til sjuende og sist er det resultatet som teller. Callan og Arena er for øvrig nøye med å påpeke at indoktrinering og «closed-mindedness» kommer i grader, og at de ikke nødvendigvis er permanente tilstander - det er fullt mulig (om enn krevende og smertefullt) å frigjøre seg fra sin egen indoktrinerte tilstand. Uansett definisjon blir indoktrinering en anti-kritisk virksomhet.

En indoktrinert, lukket bevissthet hos elever og studenter (og andre) er en bevissthet som ikke er villig til eller er ute av stand til selv å vurdere begrunnelser for oppfatningene, "svarene», elevene har fått seg kastet i hodet. Det er en bevissthet som unngår å forholde seg til alternative oppfatninger fordi den er blitt sterkt følelsesmessig tilknyttet «svaret», tror sterkt at svaret er riktig og har forpliktet seg på å stå for det. Vi skal ikke undervurdere folks følelsesmessige investeringer i bestemte synspunkter. Også forskere kan bli vel glade i sine egne teorier. En som tror uten begrunnelse (evidens), uten å spørre eller undersøke, kan beskrives som godtroende og blindt aksepterende, som Grue-Sørensen sier.

Her skal vi koste på oss en liten omvei innom Alexander Pope (1688-1744). I 1709 utga han An Essay on Criticism, som kanskje best kan beskrives som et lærd dikt om poesi og poesikritikk. I to lange vers som (blant annet) handler om forholdet mellom deler og helhet, sier han: "All comes united to the admiring eyes» (s. 8). Man kan tolke Pope på mange måter. I min kontekst her setter jeg dette inn i samme ramme som godtroenhet og blind aksept: det beundrende blikket, som ser en vakker helhet og enten ikke ser eller velger å overse deler som ikke "går opp», som er i konflikt eller som mangler. Men som Pope sier to linjer senere: «Whoever thinks a faultless piece to see. Thinks what ne'er was, nor is, nor e'er shall be» (s. 8).

Én ting er å beundre noen blindt og akseptere påstander uten evidens, noe annet og mer alvorlig er å holde fast ved sin overbevisning selv om man har kjennskap til gode moteksempler, motargumenter og negativ evidens. På den andre siden skal ikke indoktrinering få skylda for all ukritisk tenkning. Generell tankemessig latskap kan også resultere i manglende kritisk tenkning og holdning.

Nå forlater vi motsatsene en stund og tar en rask vandring i det begrepsmessige omlandet. Det kan også være nyttig når man skal ringe inn et begrep. Jeg skal ikke foreta noen komplett kartlegging, men tilstrekkelig til å antyde at begrepsmessige landskap kan være særs komplekse og gjøre at vi må ta nye runder med begrepet vi startet med. La oss først se på «open-mindedness», et begrep som er mye diskutert i pedagogisk litteratur. I likhet med mistanken er en åpen tanke en tanke som ikke har bestemt seg i utgangspunktet, men som ivaretar alternativer, andre innfallsvinkler og synsmåter. Den pedagogiske filosofen William Hare (1979) karakteriserer «open-mindedness» på følgende måte:

A person who is open-minded is disposed to revise or reject the position he holds if sound objections are brought against it, or, in the situation in which the person presently has no opinion on some issue, he is disposed to make up his mind in the light of available evidence and argument as objectively and as impartially as possible. [...] We may adopt the attitude of open-mindedness with respect to highly 
particularized and specific beliefs or to more general and wide-ranging hypotheses, theories, and conceptual frameworks. The object of one's open-mindedness varies, but the meaning of open-mindedness remains constant (s. 9).

Grue-Sørensen, som vi har sett, kopler kritisk holdning til et kontinuum mellom lukket og åpen bevissthet, men uten å utvikle noen argumentasjon rundt det. Den kritiske holdningen holder seg åpen for andre mulige forklaringer. Den ukritiske er lukket, og mener å ha funnet den eneste mulige forklaringen. Så kan man diskutere hvordan "open-mindedness» forholder seg til kritisk tenkning. Er de sideordnet? Er det ene mer fundamentalt enn det andre? Nødvendig? Jeg heller til at «openmindedness» er nødvendig for det pedagogisk kritiske, men ikke tilstrekkelig. Det er nødvendig fordi den kritiske holdningen trenger flere alternativer å jobbe med, flere innfallsvinkler. En ukritisk holdning klarer seg med, og forplikter seg kanskje på, ett alternativ som ikke undersøkes nøyere, men bare aksepteres. Open-mindedness er derimot ikke tilstrekkelig. For hvor åpne skal vi være? Og ikke minst, hvordan skal vi forholde oss til alle alternativene vi er åpne for? Det ville være nettopp godtroende og naivt å tenke at alle alternativer er like gode, og at det ikke spiller noen rolle hvilket av dem vi lander på til slutt. Vi blir ikke automatisk kritiske av å ha et åpent sinn, og «open-mindedness» er derfor ikke tilstrekkelig for en kritisk holdning. Med andre ord må vi bekymre oss om kvaliteten på den åpne tenkningen vår. En person som er åpen kan også tenke feil og resonnere dårlig, eller ikke komme noe videre med alle alternativene som undersøkes.

Mye av dette tar Hare høyde for: «... a person must be both willing and able to revise his own position if he is to be open-minded", sier han (s. 8). En person med en åpen bevissthet har vilje til å revidere eller til og med avvise et synspunkt han eller hun selv har, hvis det kommer gode, solide innvendinger mot dette synspunktet. Dette betinger at kvaliteten på de eventuelle innvendingene må vurderes - uholdbare innvendinger kan ikke telle som motargumenter. En kritisk tenker må kunne tenke kritisk om sin egen åpenhet, om alternativene, og om revideringen av egne oppfatninger. «Open-mindedness» er åpenbart et verdig mål for pedagogisk virksomhet. Det krever tid, tålmodighet, toleranse for motsigelser og anledning til tvil og utprøving.

Et annet sentralt begrep i det begrepsmessige omlandet er autonomi. I likhet med «open-mindedness» anses autonomi å være et verdig utdanningsmål i seg selv; eventuelt i form av kriteriet "selvstendig tenkning», som vi bruker i evaluering av eksamensbesvarelser eller masteroppgaver. «Autonomi» kommer fra det greske avtó (autos,

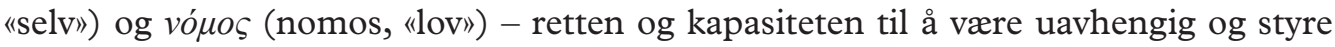
seg selv, til å leve på måter bestemt ut fra egne grunner og motiver og ikke være offer for eller bli undertrykt av eksterne krefter (Callan, 1994). Hvordan er så autonomi og en kritisk holdning relatert til hverandre? Må du være autonom for å kunne tenke kritisk? Det kan synes å være nærliggende, men å gjøre autonomi til en nødvending betingelse for kritisk tenkning innebærer at undertrykte personer ikke kan tenke kritisk, og det er ikke riktig. Er det omvendt, at kritisk tenkning er nødvendig for å være autonom? Ja, kanskje heller det. 


\section{T. Kvernbekk}

\section{Opplaring til det kritiske}

Undervisning er en målrettet aktivitet. Den kan for eksempel ha autonomi, «open-mindedness» eller kritisk tenkning som overordnete mål. Her skal jeg først minne om at mål som er gode hver for seg, kan være i konflikt med hverandre. David Labaree (2008) sier det slik: «In fact, what is helpful in attaining one goal may be harmful in attaining another, which, for example, is the argument made by proponents of critical thinking about the effects of efforts to raise test scores» (s. 422).

Jeg ser ikke bort fra at undervisning kan inneholde elementer av indoktrinering, men vi må kunne skille disse to fra hverandre. Det setter i utgangspunktet noen rammer for undervisning når det gjelder hensikter, undervisningsmetoder (særlig behandlingen av doktrinært innhold) og hva slags epistemiske holdninger til innholdet vi ønsker at elevene skal sitte igjen med til slutt. Det er forskjell på å ha kunnskap om en religion og å tro fullt og fast på sannheten av den.

Det finnes mange tilnærminger til undervisning. Vi kan begynne med den amerikanske pedagogiske filosofen Israel Scheffler (1923-2014). Han diskuterer ulike modeller og faller ned på følgende:

He [læreren] must rely on the critical spirit of rational dialogue and critical reflection for the development of character, acknowledging that this implies the freedom to reject as well as accept what is taught. [...] What is in point here is simply the autonomy of the student's judgment, his right to seek reasons in support of claims upon his credibilities and loyalties [...] (1973, s. 77-78).

Det er en dobbelthet i dette som er karakteristisk for mye undervisning, kanskje særlig i høyere utdanning. Scheffler unngår å kaste svar i hodet på studentene. Læreren skal så å si presentere premissene, og så kan elevene trekke sine egne konklusjoner og finne svarene selv. De kan utøve sin autonomi og bruke sin frihet til å avvise eller akseptere innholdet, alt ettersom. Men: de må bruke de allment aksepterte prinsippene for diskusjon og vurdering av evidens og begrunnelse. «Our teaching needs thus to introduce students to those principles we ourselves acknowledge as fundamental, general, and impartial, in the various departments of thought and action", sier Scheffler (s. 80). Hvis du vil avvise eller kritisere disse prinsippene, må du bruke de samme prinsippene til å gjøre det. Kritikken har sine normer.

Hvordan vil så dette se ut i praksis? Grue-Sørensen påpeker at undervisning i skolen beskjeftiger seg med etablerte og velfunderte sannheter som elevene ikke har saklige muligheter til å trekke i tvil. Etter litt diskusjon konkluderer han:

Vi må altså sikkert erkende, at man ikke kan opdrage til en ægte kritisk indstilling hverken ved dressur eller træning, og heller ikke ved utstædelsen af råd og formaninger, som eleverne kan følge; end ikke om de indser fornuften i disse råd (1974, s. 42).

Så hva gjør vi? Grue-Sørensen skriver både jordnært og engasjerende om dette. I alle fall må vi involvere elevene i praktiseringen av kritikk, sier han. Det betyr at 
undervisningen må ta opp problematiske og kontroversielle temaer. Hva slags temaer kan så det være? Tja. Man skal ikke kaste elever ut i kritikk de ikke har forutsetninger for å makte. Det er heller ikke lurt å velge temaer utelukkende for det formål at elevene skal øve sin kritiske sans på dem. Hvis et fag omdannes til å bli bare en øvelse i kritisk tenkning, så blir resultatet ikke en kritisk innstilling, men dens vrengebilde: utilfredshet, kverulering, negativisme og kranglevorenhet. Hva så hvis en elev som er stillferdig og beskjeden av seg brenner inne med en genuint kritisk reaksjon? Om dette problemet sier Grue-Sørensen:

Og dog, og dog; hvis dette siste tilfælde analyseres rigtigt, så vil jo selv den, der brænder inne med en kritik, som ellers brænder ham på tungen, have været kritisk i sit hjerte; og den eneste mangel er, at han ikke får denne kritik efterprøvet ved denne lejlighed. Men kritisk har han været, og det har han ikke skullet lære. Hvad han kunne have lært, hvis kritiken var blevet taget op, var egentlig ikke at være kritisk eller at forholde sig kritisk, men at formulere sig, at diskutere og at argumentere (s. 45).

Argumentasjon er ikke selv kritikk, men et instrument for kritikken. Dette er et interessant poeng og representerer en utfordring for en god del av den anglo-amerikanske litteraturen om kritisk tenkning, hvor kritisk tenkning operasjonaliseres som argumentasjon og relasjonen mellom de to derfor er så tett at det er nærliggende å oppfatte dem som identiske (se f.eks. Ennis, 1987). Selv om argumentasjon er sentralt for kritikk, som Scheffler sier, trenger ikke det bety at kritikken ikke kan benytte seg av andre instrumenter. Hvilke kan være et tema for pedagogisk utforskning.

Vekten på argumentasjon som kritikkens instrument kan henge sammen med at kritisk tenkning i anglo-amerikansk tapning utøves på nettopp argumenter, på påstander, diskurser, teorier eller oppfatninger mer allment. Her skal vi se litt på kritisk teori og forsøk på å lage en kritisk didaktikk. Men dette er ikke det samme som kritisk tenkning slik vi har møtt den så langt. «Kritisk teori» rommer ikke bare kritikk av påstander og oppfatninger, men kritikk av vitenskap og samfunn mer allment. Begrepet kan forstås både som smalt og bredt, sier James Bohman (2005); den smale forståelsen assosieres med Frankfurter-skolens nymarxistiske perspektiver, den brede med de mange sosiale bevegelsene som retter seg mot varierende dimensjoner ved og former for undertrykkelse og diskriminering. I begge tilfellene gir kritisk teori både deskriptivt og normativt grunnlag for sosiale undersøkelser som har til hensikt å redusere dominans og øke frihet. Her er det ikke (bare) teorier og påstander som kritiseres, men samfunnssystemet (dets organisering, verdier, m.m.), vitenskapen (dens rolle i samfunnet, forskerrollen, m.m.) og alle former for ideologi. Max Horkheimer (1895-1973), en av Frankfurter-skolens grunnleggere, sier at kritisk teori skiller seg fra «tradisjonell» teori ved at den har en praktisk hensikt. Den skal søke frigjøring og bidra til å skape en verden som ivaretar menneskenes behov og evner (1972, s. 246). Men i kritikk av samfunn, vitenskap og ideologi må man jo også bruke kriterier. Hvor kommer de fra? Hvem har bestemt hva de skal være og hvordan er de begrunnet? 


\section{T. Kvernbekk}

Bohman kommenterer det slik: "[A critical theory] must explain what is wrong with current social reality, identify the actors to change it, and provide both clear norms for criticism and achievable practical goals for social transformation» (s. 1). Kritikken av det bestående risikerer å bli ensidig og enøyd, med bastante svar på spørsmål om hva som er riktig og feil, bra og dårlig. Det er ikke for ingenting at (klassisk) kritisk teori selv kan kritiseres for å være absolutistisk (Vestergaard, 1985).

Kritisk pedagogikk er utviklet i mange retninger, og det går fint an å adoptere noen av elementene uten å erklære seg som nymarxist. For eksempel vil jeg mene at ideen om skjult påvirkning har stort kritisk potensial. Begrepet «skjult læreplan» kunne gjenopplives, gis en skjønnsom nytolkning uten konspiratoriske overtoner og f.eks. videreutvikles i retning av å studere pedagogiske bivirkninger. For en ting er at elever lærer seg det innholdet og de ferdighetene vi har bestemt at de skal lære. Noe helt annet er det barn og elever lærer seg som en konsekvens av måten vi organiserer undervisningen på, av måten vi kommuniserer på, av måten det sosiale, fysiske og digitale rommet er innredet på, etc. - ting vi lærer som en bivirkning av måten vi lærer innhold og ferdigheter på. Hva lærer barn av å bli testet, av å bli evaluert til stadighet? Kanskje lærer de at gode (test)resultater verdsettes, mens prosesser ikke er så nøye; de lærer å finne seg i å bli evaluert i alt de gjør; eller enda verre - de lærer at de ikke mestrer, og at de er tapere i skolesystemet. Her kan vi kople på pedagogiske risikovurderinger også, som det antakeligvis gjøres altfor lite av. Hva er risikoen for uheldige og negative bivirkninger hvis vi organiserer klasserommet i evnebaserte grupper? Hvis vi iverksetter et tiltak for å endre elevatferd som er basert på et belønningssystem? For ordens skyld: uplanlagte konsekvenser kan også være positive.

Åpenbart kan ikke en kritisk pedagogikk kaste svar i hodet på elevene. De skal ha en reell mulighet til å finne sine egne svar. Ikke desto mindre finner vi også her det samme paradokset som vi finner så mange andre steder i pedagogikken: hvordan stille opp retningslinjer for en kritisk didaktikk, med mål, innhold og metoder, og samtidig være kritisk? I det sekund vi lager en kritisk didaktikk, slutter den å være kritisk, den stivner og blir sedvane, den blir selv den autoriteten den ønsker å utfordre. Men det avhenger av hva slags frihets- og autonomibegrep vi holder oss med, hvor mye medbestemmelse vi synes er fornuftig, og om vi tenker i grader framfor absolutter.

\section{Akademia}

La oss begynne med nok en klassiker, Karl Popper (1902-1994). Kritikk er forskningens modus operandi, sier Popper (1991). Vitenskapens mål er sannhet, og vitenskapens metode er kritikk. Med «kritikk» som metode mener han som kjent empirisk testing av teorier og hypoteser med det mål for øye å falsifisere dem. Teorier som ikke er prinsipielt falsifiserbare, gjelder ikke som vitenskapelige, sier Popper (akkurat dét kan man nok diskutere). Mer interessant i vår sammenheng her, er hans utlegning av det han kaller kritisk holdning og dogmatisk holdning. Dogmatisme tilhører åpenbart kritikkens motsatser. Popper identifiserer dogmatisk tenkning som et psykologisk 
fenomen: vår tilbøyelighet til å se regelmessigheter og mønstre overalt og derfor forvente å finne dem (også der det ikke er noen). De som inntar en dogmatisk holdning holder fast ved slike forventinger og oppfatninger også når evidensen taler mot dem, noe som indikerer en sterk tro på sannheten av oppfatningen - enten de er indoktrinert eller ikke. En kritisk holdning, derimot, "which is ready to modify its tenets, which admits doubt and demands tests, is indicative of a weaker belief» (s. 49). Dette er temaer jeg allerede har vært innom: Poppers dogmatiske holdning gjenkjennes i en bevissthet som lukker alternative synpunkter ute og binder seg sterkt til sannheten av en bestemt oppfatning (Callan \& Arena, 2009). Den gjenkjennes også i det som kalles "confirmation bias"; tendensen vi har til å søke bekreftelse av våre oppfatninger, lete etter positiv evidens, etter det som stemmer overens med det vi allerede tror og unngå argumenter og evidens som kan utfordre våre oppfatninger:

For the dogmatic attitude is clearly related to the tendency to verify our laws and schemata by seeking to apply them and to confirm them, even to the point of neglecting refutations, whereas the critical attitude is one of readiness to change them - to test them; to refute them; to falsify them, if possible (1991, s. 50).

Poppers beskrivelse av denne kritiske holdningen er viktig. Det handler om måten vi holder våre oppfatninger på; om vi tviholder på dem uansett, eller om vi er villige til å oppgi dem hvis vi møter negativ evidens og motargumenter, etter at disse er vurdert som holdbare og tungtveiende (de må vurderes og verken avfeies eller aksepteres uten videre). Derfor hører "open-mindedness» med i dette bildet, som den kritiske holdningens tvilling - nødvendig både for å unngå en dogmatisk holdning og for å kunne innta en kritisk holdning, men i seg selv ikke tilstrekkelig. Kritisk holdning er et must $i$ akademia, ettersom akademia drives av meningsmangfold, faglig uenighet, brytninger og diskusjon. En tanke som erklærer seg ferdigtenkt og som har bestemt seg for hva som er riktig en gang for alle, er ikke en kritisk tanke. Heller ikke er en vimsete og ustadig tanke en kritisk tanke. Som Alexander Pope (1709) sier det: «Some praise at morning what they blame at night, But always think the last opinion right» (s. 9) - et synspunkt som åpenbart er beslektet både med å snu kappa med vinden og med det som kalles «argument from authority»; å mene at noe er riktig fordi en autoritetsperson har sagt det. Dette var for øvrig akseptert i tidligere tiders akademia, men er det ikke nå lenger (selv om man innimellom kunne ønske det...). Mistanken, slik Aarnes og Salemonsen beskriver den, en tanke som får lov til å være uferdig og søkende og utforske både positiv og negativ evidens, kan hjelpe oss til å unngå å falle i den tankemessige fellen som "confirmation bias» utgiør. Det er krevende. Men hvis ikke, kan vi få forskere som slår hverandre i hodet med absoluterte synspunkter og vil innføre «no-platforming» for meningsmotstandere. Det er Paul Tillichs tese om det fatale pedagogiske mistaket overført til akademia.

Hvordan skaper vi så en kultur med plass til tanker som er underveis, som tar omveier, veier for og mot, og som unngår det vrengebildet Grue-Sørensen advarer mot, nemlig kritikk som kverulering, krangel og negativisme? Her er det er ingen 


\section{T. Kvernbekk}

mangel på litteratur; hele det store argumentasjonsteoretiske feltet er fullt av forslag til rasjonelle spilleregler og dialogiske framgangsmåter for meningsbrytning (se f.eks. van Eemeren, 2002; Johnson, 2000). Diskusjonen, i likhet med kritikken, har sine normer - alt fra respekt for motstander, saklighet og høflighet i innvendingene som reises og saklighet og høflighet i responsene til hva som er lurt å se etter når man skal undersøke holdbarheten av andres (eller egne) argumenter (eksempelvis evidensens sannhet, relevans og tilstrekkelighet). Litt paradoksalt, kanskje, velger jeg her å se litt nærmere på en argumentasjonsstrategi som er problematisk, men fristende. Den er ganske utbredt både i akademia og i dagliglivet: å subjektivisere både synspunkt og kritikken av synspunkt. Det er den strategien vi bruker når vi nøytraliserer egne og andres påstander og giør dem immune mot kritikk og diskusjon: «Dette er jo bare din (min) mening», sier vi da. Denne strategien er mindre konfronterende enn eksplisitt absolutering av eget synspunkt og bastant avfeiing av all tvil og alle motargumenter. Men det vi i realiteten giør, sier Claudia Ruitenberg (2013), er å viske ut skillet mellom preferanser og påstander om hvordan noe er. Vi behandler påstander som om de bare er uttrykk for preferanser og smak, og erstatter dermed pluralisme i synspunkter, som er legitimt, med relativisme, som er tannløst og verken fremmer debatt eller innsikt. Vi gidder ikke diskutere sannheten eller holdbarheten av andres subjektive preferanser og smak, og det gir ikke mening å be folk om å begrunne dem heller. Dermed blir synspunkter immune mot kritikk. Det er vesentlig, argumenterer Ruitenberg, å opprettholde en distinksjon mellom preferanser og påstander. Det samme gjelder i klasserommet, sier hun, også der kan det under diskusjon framkomme synspunkter som er av en slik art (f.eks. nedsettende påstander om minoriteter) at læreren ikke kan la eleven slippe unna med så å si ting som «ja, det er nå din mening» eller «jeg respekterer ditt syn» eller «alle har rett til sitt eget syn på dette.» Diskusjon skal ha kriterier og normer:

Pluralism can only be sustained by ongoing public conversation about the sets of values that should or should not guide the lives of members of the diverse polity. The refusal to expose one's own opinions to the scrutiny and potential disagreement of others is a refusal to engage in the public qua public. When «that's just my opinion» is used to shield one's views from public scrutiny or "that's just your opinion" is used to disavow one's responsibility to engage another's views, these phrases do not belong in the classroom (2013, s. 114-115).

For akademias del kan vi legge til at forskere som velger subjektivisering som strategi også giør seg selv seg selv uinteressante. Det er det neppe noen forskere som ønsker vel kan det være fristende å immunisere egne teorier, hypoteser og synspunkter mot kritikk, men prisen å betale er i drøyeste laget.

Hva så med forskere som er med i de mange sosiale bevegelsene vi har i dag, rettet mot ulike former for undertrykkelse og diskriminering; eksempelvis antirasisme, identitetspolitikk, avkolonisering eller annet, og slik sett representerer kritikk av det bestående? Dette skal ikke handle om deres ytringsfrihet, som ellers er mye diskutert 
om dagen, men om noe annet: hvordan kan (aktivistisk) kritikk kombineres med metodologiske krav, data-sentrisk forskning og «big data»? Her har det kommet interessante diskusjoner de senere årene, og jeg skal bare antyde et par momenter. For eksempel er det en spenning mellom kritikk av sosial struktur og kartlegging eller bruk av den samme strukturen, sier Long og Baker (2019):

Categories, structures, patterns: for the cultural critic, these are to be questioned, critiqued, speculatively reimagined. In contrast, when working at a command line [dvs. en typisk "workflow» med datainnsamling, organisering av data, analyse og tolkning av resultater], categories, structures and patterns are to be used and discovered. For example, ethnicity and gender may be socially conditioned and thus fluid, but the researcher studying their effects on cultural production must treat both as finite and discrete (s. 196).

Videre, sier Long og Baker, er det ikke gitt at et forskningsprosjekt er «kritisk», eller på hvilken måte det er kritisk, ettersom resultater gjerne kan tolkes på flere måter og støtte andre tolkninger enn den kritiske. Det er vanskelig å forene sosial kritikk med metodologi som skiller mellom resultat og tolkning, og det er ikke enkelt å definere hva slags konkrete forutsetninger som må bygges inn i forskningsprosjekter for å gjøre dem «kritiske», uten samtidig å legge inn konklusjonene også. Long og Baker argumenterer for at innsamling og organisering av data er betydelig mer tilgjengelige for kritisk innsikt enn statistisk behandling og tolkning. Her bør det ligge an til mange interessante metodologiske og teoretiske diskusjoner, tenker jeg.

Til sist skal vi streife innom nok en klassiker, nemlig Elliot Eisner (1933-2014) og hans begrepspar "connoisseurship and criticism» (Eisner, 1985). Dette begrepsparet befinner seg i grenselandet mellom forskning og praksis; som forskning er det uortodokst, og som praksis er det ekstremt tidkrevende og det er uklart hvem som gjør det. Det er ikke kritisk tenkning og heller ikke kritisk teori, men en form for kritikk som handler om evaluering av flyktige, unnvikende og ideografiske fenomener, som f.eks. livet i et klasserom. Her handler det ikke primært om å måle effekter eller kartlegge resultater, men om å granske, verdsette og klarlegge kvaliteter ved det som foregår i klasserommet: «... the major contribution of evaluation as contributing to a heightened awareness of the qualitites of that form of life» (s. 92). Til dette trengs en "connoisseur», en kjenner med et velutviklet blikk for detaljer og nyanserikdom, som kan gripe fatt i underliggende og vanskelig tilgjengelige strømninger. Hva er den pedagogiske verdien av det som skjer? Hvordan ser denne kompleksiteten ut, hva er dens kvaliteter og karakteristika? Hva er vedvarende og hva er flyktig? Dette er kunstkritikk anvendt på pedagogiske fenomener, prosesser og situasjoner. Det krever kunnskap, følsomhet, lydhørhet og godt blikk - og tid, kan vi legge til. Kritikk kommer inn i bildet som denne evalueringens offentlige uttrykk og forutsetter dermed "connoisseurship," men ikke omvendt. Denne formen for kritikk er ikke argumentasjon, i betydningen evaluering av påstander, men en vurdering av kvalitet som minner om kunstkritikk, som Eisner selv påpeker. Det er ingen som påstår at dette er en 


\section{T. Kvernbekk}

enkel form for vurdering. Men den er verdt å minne om i en tid hvor vi stirrer oss blinde på mål i form av kompetanser, og evaluering mest handler om i hvilken grad målene oppnås. Ikke noe galt om kompetanse, men Eisner har uten tvil rett i at klasseromslivet er mer enn det. Hvordan skal vi så vurdere en slik kritikk? Hvilke kriterier skal vi bruke? Det er ikke lett å si. Som et minimum skal vi, sier Eisner, passe på at de fakta som er klarlagt i situasjonen ikke ignoreres og at bitene passer sammen. Det kan vi forstå som et krav om koherens. I tillegg ligger det et sannhetskrav i betydningen korrespondanse med fenomenet der - det kritikken sier at den beskriver, tolker og evaluerer må finnes i fenomenet. Kritikeren skal ikke se mønstre eller regelmessigheter som ikke er der. Bortsett fra det, er dette er veldig fjernt fra Poppers syn på kritikk og kritikkens funksjon. Dette er ikke empirisk testing av hypoteser, det er ingen forsøk på falsifisering, selv om fakta må respekteres. "The task of the critic is to help us see», sier Eisner (s. 93). Det er vidunderlig uklart hvem «us» er, og hva vi eventuelt kan gjøre med det den kritiske "connoisseuren» lærer oss å se. Men Eisners tenkning om evaluering og kritikk bør gjenopplives - den kan utgjøre en motvekt mot overdreven vekt på målbare resultater fordi den, selv med sine uklarheter, forutsetter en kompleks og nyansert forståelse av praksis og livet i klasserommet. Vi må motarbeide illegitime forenklinger som fører til at praksis identifiseres med bare én dimensjon.

\section{Avslutning}

Kritikk kan være så mangt. Mange ulike ting kan kritiseres for mye og på mange ulike måter. Noe kritikk vil være velfortjent. Også kritikken kan kritiseres; den kan være basert på misforståelser, eller den kan være rigid og absolutistisk. Kritikk er vel og bra. Kritikk av kritikken er også vel og bra. Men begge må følge alminnelige normer for argumentasjon, evidens, underbygging av argumenter og en allmenn vilje til å la egne oppfatninger og påstander bli underkastet andres evaluering og å engasjere andres oppfatninger på en seriøs måte. Og hvorfor må vi følge slike normer? Fordi det $\mathrm{i}$ bunnen for all kritikk ligger verdier som riktighet, troverdighet, aksepterbarhet og saklighet.

På mange måter er det pedagogisk kritiske en delikat affære. Det å framelske en kritisk holdning hos elever og studenter er også en delikat affære. Det er viktig å være fagkritisk, men et fag som f.eks. pedagogikk er også noe annet og mer enn bare en øvelsesarena for kritikk. Utvikling av kritisk holdning krever øvelse, men det å øve seg i kritikk er noe annet og mer enn å finne problemer og feil. Vi må unngå å havne i kritikkens vrengebilde med negativisme og kranglevorenhet. Vi må også unngå å bli absolutistiske og kaste skråsikre svar i hodet på meningsmotstandere og diskusjonspartnere. Kritikk krever "open-mindedness» og at man kan leve med uferdige tenker, både egne og andres. Jeg tror at Poppers kritiske holdning har mye for seg i akademia. Den gjelder måten vi har våre oppfatninger på og innebærer en vilje til å revidere sine egne synspunkter i lys av motargumenter og negativ evidens som vurderes som god og holdbar - men motargumenter og negativ evidens skal vurderes, noe annet ville 
være godtroende. Det er fint med tenkning som har omveier. Men en tenkning som tar omveier hele tida og aldri lander på noe standpunkt, og slik sett unngår kritisk blikk, blir for vanskelig å leve med i lengden. Vi må kunne holde noe for sant, ha overbevisninger og respektere fakta - men, med en passe dose mistanke. Fakta er kanskje ikke det de gir seg ut for å være. Det er heller ikke hugget i stein at nyere tenkning er bedre enn gammel. Alexander Pope får derfor siste ord: «Regard not then if wit be old or new, But blame the false, and value still the true» (1709, s. 12).

\section{Referanser}

Bohman, J. (2005). Critical theory. I E. Zalta (Red.), Stanford encyclopedia of philosophy. https://plato.stanford. edu/entries/critical-theory/

Callan, E. (1994). Autonomy and alienation. Fournal of Philosophy of Education, 28(1), 35-53. https://doi. org/10.1111/j.1467-9752.1994.tb00311.x

Callan, E. \& Arena, D. (2009). Indoctrination. I H. Siegel (Red.), Oxford handbook of philosophy of education. Oxford University Press. https://doi.org/10.1093/oxfordhb/9780195312881.003.0007

Collett, J. P. (1998). På jakt efter universitetets idé. Filologen - Historisk-filosofisk fakultetstidsskrift, 2, 1-6.

Eemeren, F. H. van (2002). Advances in pragma-dialectics. SicSat.

Ennis, R. H. (1987). A taxonomy of critical thinking dispositions and abilities. I J. B. Baron \& R. J. Sternberg (Red.), Teaching thinking skills: Theory and practice (s. 9-26). W. H. Freeman.

Eisner, E. (1985). The art of educational evaluation. A personal view. The Falmer Press.

Grue-Sørensen, K. (1974). Knud Grue-Sørensen. Pedagogisk perspektiv (Utvalg ved T. Harbo, A. Lysne \& L. Stenhouse). Aschehoug.

Hare, W. (1979). Open-mindedness and education. McGill-Queen's University Press.

Holberg, L. (1869). Erasmus Montanus, eller Rasmus Berg: Komedie i fem Akter. E. C. Løser. (Opprinnelig utgitt 1731)

Horkheimer, M. (1972). Critical theory. Seabury Press.

Johnson, R. (2000). Manifest rationality. A pragmatic theory of argument. London: Routledge.

Labaree, D. (2008). The dysfunctional pursuit of relevance in education research. Educational Researcher, 37(7), 421-423. https://doi.org/10.3102/0013189X08325557

Long, S. \& Baker, J. (2019). The elusive digital/critical synthesis. I M. K. Gold \& L. F. Klein (Red.), Debates in the digital humanities 2019 (s. 195-199). University of Minnesota Press.

Pope, A. (1709). An essay on criticism. Poetry Foundation. https://www.poetryfoundation.org/articles/69379/ an-essay-on-criticism

Popper, K. R. (1991). Conjectures and refutations. Routledge.

Ruitenberg, C. (2013). "That's just your opinion!» American Idol and the confusion between pluralism and relativism. I W. Hare \& J. P. Portelli (Red.), Philosophy of education. Introductory readings (s. 109-115). Brush Education.

Scheffler, I. (1973). Reason and teaching. Hackett Publishing Co.

Siegel, H. (1988). Educating reason: Rationality, critical thinking, and education. Routledge.

Vestergaard, E. (1985). Pcedagogisk filosofi. Munksgaard.

Aarnes, A. \& Salemonsen, H. (1987). (Red.). Tanke og mistanke. Til belysning av fornuftskrisen $i$ vår tid. Aventura Forlag. 